\title{
Reinstatement of the Loyalty Islands Sandalwood, Santalum austrocaledonicum var. glabrum (Santalaceae), in New Caledonia
}

\author{
Jean-François Butaud ${ }^{1,2}$ \\ I Conservation International, 58 bis avenue de la Victoire, 98800 Nouméa, New Caledonia 2 Consultant in \\ forestry and Polynesian botany, P.O. Box 52832 - 98716 Pirae, Tahiti, French Polynesia \\ Corresponding author: Jean-François Butaud (jfbutaud@hotmail.com)
}

Academic editor: D. Nickrent | Received 17 August 2015 | Accepted 2 October 2015 | Published 9 October 2015

Citation: Butaud J-F (2015) Reinstatement of the Loyalty Islands Sandalwood, Santalum austrocaledonicum var. glabrum (Santalaceae), in New Caledonia. PhytoKeys 56: 111-126. doi: 10.3897/phytokeys.56.5924

\begin{abstract}
Sandalwoods encompass 19 species restricted to southeast Asia and the Pacific. The species Santalum austrocaledonicum Vieill. (Santalaceae) is endemic to New Caledonia (Grande-Terre, Isle of Pines, Loyalty Islands) and Vanuatu, where several varieties are recognized. The Loyalty Islands sandalwood variety is here reinstated as Santalum austrocaledonicum var. glabrum Hürl. emend. Butaud \& P.Firmenich, mut. char. It was previously considered a synonym of the type variety; however, new morphological and genetic studies confirmed its distinctiveness. The key for New Caledonian varieties of Santalum austrocaledonicum has been updated and a short description of its essential oil composition and organoleptic quality is given.
\end{abstract}

\section{Keywords}

Santalum austrocaledonicum, Santalaceae, Loyalty Islands, New Caledonia, essential oil

\section{Introduction}

Sandalwoods are shrubs or small trees well known for the essential oil extracted from their fragrant heartwood and used in perfumery. They belong to the genus Santalum (Santalaceae) comprising 19 species restricted to southeast Asia and the Pacific (Harbaugh and Baldwin 2007, Harbaugh 2007, Harbaugh et al. 2010). The most soughtafter species is the Indian sandalwood, Santalum album L. 
Santalum austrocaledonicum Vieill. is the only native sandalwood in New Caledonia and Vanuatu (Guillaumin 1925, Hallé 1988, Harbaugh and Baldwin 2007), and is endemic to these archipelagoes. It has been heavily harvested for the past 150 years (Shineberg 1967) and its wood is still exploited for the fragrance industry as its essential oil can be considered as a substitute for Indian sandalwood oil (Braun et al. 2005).

The most recent taxonomical work on $S$. austrocaledonicum was carried out by Hallé (1988) who recognized three botanical varieties based on specimens from New Caledonia in Paris $(\mathrm{P})$ herbarium:

- S. austrocaledonicum Vieill. var. austrocaledonicum from Grande-Terre (main island of New Caledonia), Isle of Pines, Loyalty Islands and Vanuatu;

- S. austrocaledonicum var. pilosulum N.Hallé in the vicinity of Nouméa on the southwest coast of Grande-Terre;

- S. austrocaledonicum var. minutum N.Hallé from the northwest coast of Grande-Terre.

Since that revision, several studies have shown the great morphological variations of var. austrocaledonicum in New Caledonia and Vanuatu which are linked to geographical distribution (Quemin 1988, Nasi 1995, Chauvin and Ehrhart 1998, Bottin 2006, Bouvet et al. 2005, Bottin et al. 2007). The main differences in New Caledonia can be summarized as follows:

- Loyalty Islands: large seeds $(\mathrm{L}=8-11 \mathrm{~mm}, \mathrm{D}=7-10 \mathrm{~mm})$, short and wide juvenile leaves $(\mathrm{L}=30-52 \mathrm{~mm}, \mathrm{~W}=8-15 \mathrm{~mm})$;

- Isle of Pines: medium-sized seeds $(\mathrm{L}=8-10 \mathrm{~mm}, \mathrm{D}=6-9 \mathrm{~mm})$, long and narrow juvenile leaves $(\mathrm{L}=25-76 \mathrm{~mm}, \mathrm{~W}=2-10 \mathrm{~mm})$;

- Grande-Terre: small seeds $(\mathrm{L}=6-9 \mathrm{~mm}, \mathrm{D}=5-7 \mathrm{~mm})$, long and very narrow juvenile leaves $(\mathrm{L}=52-70 \mathrm{~mm}, \mathrm{~W}=2-4 \mathrm{~mm})$.

No comprehensive study of the variation of these characters is available in Vanuatu due to lack of herbarium specimens from most of sandalwood populations there.

For this reason, Nasi (1994) intended to describe the Loyalty endemic sandalwood under the variety loyaltensis but his manuscript was never published.

More recently, molecular studies of New Caledonian sandalwood showed strong genetic differentiation between islands and led to the recognition of two evolutionarily significant units, i.e. Grande-Terre and Isle of Pines for the first, and Loyalty Islands for the second (Bottin et al. 2005, 2007).

The New Caledonian sandalwood is subject to exploitation through harvesting and is grown in plantations to satisfy the increasing international demand of sandalwood essential oil. However, its taxonomy appears to be in need of revision to more precisely describe the variability of this New Caledonian biodiversity hotspot species (Myers et al. 2000) and to contribute to the sustainable management of this natural resource.

A first step of this revision is presented here, with the recognition of an endemic sandalwood variety from the Loyalty Islands based on morphological and molecular studies as well as examination of living plants and herbarium specimens. 


\section{Nomenclature}

The New Caledonian sandalwood, Santalum austrocaledonicum, was described by Vieillard (1861) from samples collected on the hills of Arama, in the Northern extremity of Grande-Terre (E. Vieillard 1090, holotype P00645808). Later, it was confirmed that this species was also present on the Isle of Pines, Loyalty Islands and Vanuatu (Guillaumin 1925, 1970, Virot 1950).

In 1964, Hürlimann described a new variety based on a sample collected on the island of Maré in the Loyalty Islands (Stauffer and Hürlimann 1964), Santalum austrocaledonicum var. glabrum Hürl. characterized by glabrous flowers, differing from the type variety (Santalum austrocaledonicum Vieill. var. austrocaledonicum) represented erroneously by samples gathered around Nouméa (Ouen Toro, Anse Vata, Baie de l'Orphelinat) which have villous flowers.

In 1988, the revision of the New Caledonian Santalum by Halle recognized the three varieties mentioned in the introduction. Hallé reduced var. glabrum of Hürlimann to synonymy under the type (autonym) variety, considering it superfluous due to confusion by Hürlimann on what was really the type of the species. Indeed, the latter described var. glabrum in comparison with what is now recognized as var. pilosulum, this one differing morphologically from var. austrocaledonicum. The true var. austrocaledonicum and var. glabrum are in fact identical relative to the morphological differences pointed out by Hürlimann in his diagnosis.

As the native Loyalty Islands sandalwoods are quite homogeneous, only one variety is to be recognized for the entire Loyalty archipelago, which is the one of Hürlimann. Thus, to reinstate the varietal name glabrum for the endemic Loyalty sandalwood, its description must be amended to distinguish it from the true type specimen.

\section{Systematics}

Santalum austrocaledonicum var. glabrum Hürl. emend. Butaud \& P.Firmenich, mut. char.

S. austrocaledonicum var. glabrum Hürl., Mém. Mus. Hist. Nat., ser. B, Bot. 15(1): 15 (1964).

Type. New Caledonia, Loyalty Islands, Maré, près de Rawa, arbre, $8 \mathrm{~m}$, en fleurs et en fruits, forêt mésophile, 17 July 1951, M.G. Baumann-Bodenheim 14762 (holotype: P scan!; isotype: Z scan!).

Diagnosis. Santalum austrocaledonicum var. glabrum is most similar to var. austrocaledonicum in its glabrous inflorescence and leaves wider than $1.5 \mathrm{~cm}$, which differentiates them from the other New Caledonian S. austrocaledonicum varieties. Santalum austrocaledonicum var. glabrum differs from S. austrocaledonicum var. austrocaledonicum by the seed size, which is more than $7.5 \mathrm{~mm}$ wide for the former and less than 7.5 $\mathrm{mm}$ for the latter. 
Description. Shrub to small tree $2-10 \mathrm{~m}$ tall, trunk up to $30 \mathrm{~cm}$ dbh; bark rough, grey to reddish-brown, longitudinally fissured; heartwood fragrant, yellowish to brownish. Leaves glabrous; petiole canaliculate, $7-13 \mathrm{~mm}$ long; blades of the mature leaves 3.5-6.0 (-6.6) × (1.6-) 2.0-3.5 $(-4.1) \mathrm{cm}$, usually elliptic or rarely obovate, apex obtuse to acute or apiculate, base acute, secondary veins mostly 7-9 pairs. Inflorescences glabrous, in axillary or terminal panicles, usually trichotomous and several times branched, with 10-40 flowers; peduncles 10-38 mm long. Flowers bisexual with outer surface of petal greenish and glabrous; pedicels 1.5-2 mm long. Petals 4, narrowly triangular, $2.5-3.0 \times 1.5-2.0 \mathrm{~mm}$, inner surface white when opening turning brownish later; petal internal margin glabrous. Stamens 4 , surrounded by long hairs at the base; the outer ones reaching the anther apex, the inner ones reflexed in the cupshaped disk; anthers 1.5-2.7 $\times$ 0.8-1.0 mm. Disk concave, more than $2 \mathrm{~mm}$ deep; disk lobes fleshy and erected between petals, $1.3-1.4 \times 0.8-0.9 \mathrm{~mm}$. Ovary unilocular, conic, acute, $1.1-1.7 \times 0.6 \mathrm{~mm}$; style free, $4 \mathrm{~mm}$ long; stigma 3 or 4 lobed. Fruit a globose fleshy drupe, 15-21 $\times 12-15 \mathrm{~mm}$ when fresh, topped by the petal scars 3-5 $\mathrm{mm}$ diameter, green turning red to deep purple and black at maturity. Seed globose, with a hard endocarp (8.5-) 9.0-11.5 × 7.5-10.0 (-10.5) mm.

Phenology. Flowering and fruiting probably occurring throughout the year but with some peaks; herbarium samples provide the following data: flowers from December to August, fruits from January to August.

Distribution. New Caledonia, endemic to Loyalty Islands; known only from Ouvéa, Lifou and Maré islands (Figure 1). Not recorded on the smaller islands of Beautemps-Beaupré, Tiga and Walpole.

Habitat and biology. This variety is restricted to the calcareous soils of uplifted atolls between 5 and $80 \mathrm{~m}$ elevation and is closely linked with traditional agriculture which consists of shifting cultivation. Regeneration by seeds occurs mainly in the open cultivated areas and young fallow lands. Loyalty sandalwood is therefore characteristic of fallows, shrublands and secondary forests, and rarely occurs in mature forests. It is also commonly found along roads and close to villages in open areas where it is generally protected and managed by inhabitants. The surrounding vegetation is often composed of trees and shrubs, such as Acacia spirorbis Labill., Acalypha spp., Acronychia laevis J.R.Forst. \& G.Forst., Dodonaea viscosa (L.) Jacq., Elattostachys apetala (Labill.) Radlk., Glochidion billardierei Baill., Melochia odorata L.f., Morinda citrifolia L., Pandanus macrocarpus (Brongn.) Solms, Podonephelium homei (Seem.) Radlk., Polyscias bracteata (R.Vig.) Lowry subsp. bracteata., Psidium guajava L., and Schinus terebenthifolius Raddi. Loyalty sandalwood is a hemiparasitic tree like all Santalum species; its pollination is insect-mediated whereas its fleshy fruits are dispersed mainly by doves and pigeons (Bottin et al. 2005).

Conservation status. Using the categories and criteria of IUCN (2001), we propose for S. austrocaledonicum var. glabrum the IUCN Red List Category Vulnerable (VU): B (1+2) ab (iii,v). Its population size is estimated at more than 10,000 mature individuals (excluding criteria $\mathrm{C}$ and $\mathrm{D}$ ) with an extent of occurrence around 8,000 $\mathrm{km}^{2}$ and an area of occupancy around $1,000 \mathrm{~km}^{2}$. Criteria A can not be used due to 


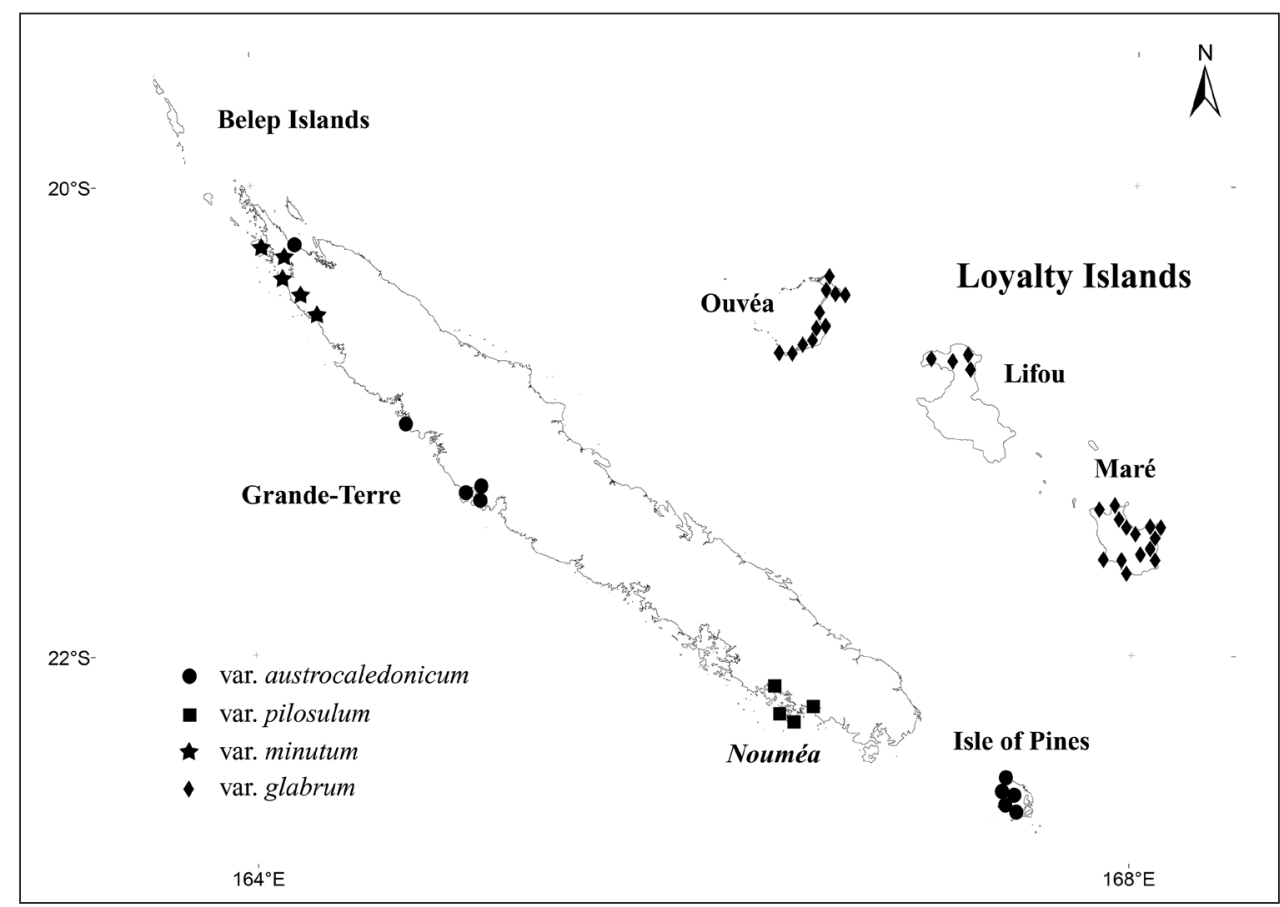

Figure I. Distribution map of New Caledonian varieties of Santalum austrocaledonicum based on the specimens examined.

lack of knowledge of generation length and magnitude of population size reduction. Three locations (one per island) can be distinguished without any fragmentation. A continuing decline is observed and projected in terms of habitat quality and number of mature individuals due to harvest, competition with invasive plant species (Schinus terebenthifolius Raddi, Pluchea odorata (L.) Cass., Lantana camara L.), hybridization with other $S$. austrocaledonicum varieties used in plantations, and changes in the traditional agricultural system (less cultivated fields, short fallows...). Indeed, despite provincial regulations establishing quota and exploitability criteria, illegal logging is still occurring (Butaud et al. 2013) whereas hybridization is suspected due to sandalwood interspecific crossability (Tamla et al. 2012).

Common names. The common names recorded for S. austrocaledonicum var. glabrum are "tapakae" (pers. obs. 2014) or "tapakai" (Lenormand 1968) on Lifou, "wekesi" (Lormée et al. 2011) on Maré and "wahata" (Ozanne-Rivierre 1984) on Ouvéa.

Discussion. Santalum austrocaledonicum var. glabrum is the sole native sandalwood in the Loyalty Islands. Nevertheless, two other varieties have been introduced for plantation purposes, mainly in Maré and Lifou: var. pilosulum from Ouen Toro in Nouméa, and var. austrocaledonicum from Isle of Pines. These plantations can be considered a risk for the Loyalty variety because of hybridization and subsequent introgression. Plantations with exotic varieties should be discouraged to preserve the 


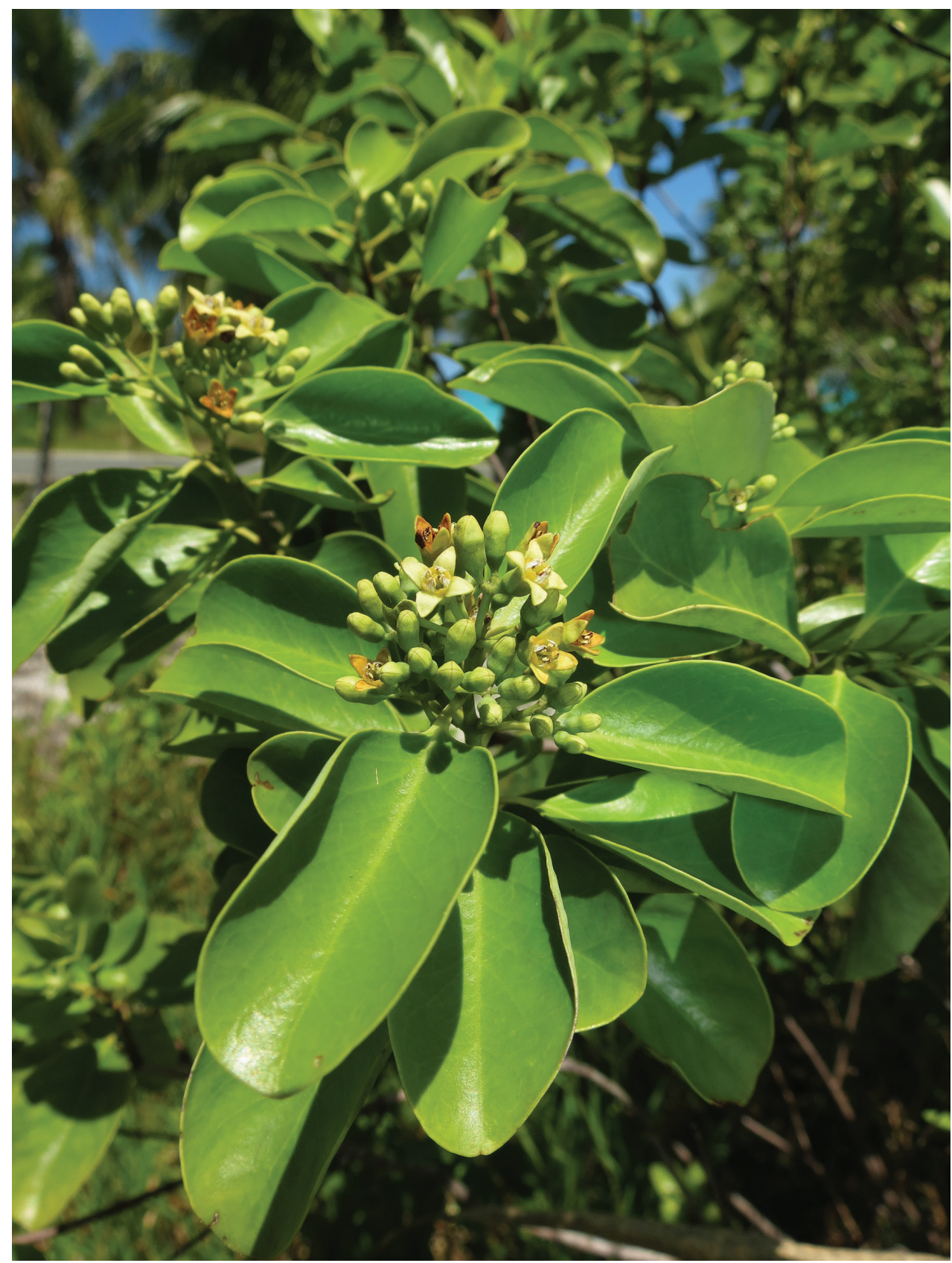

Figure 2. Flowers of Santalum austrocaledonicum var. glabrum on Ouvéa atoll in January 2015 (specimen Butaud 3414). 


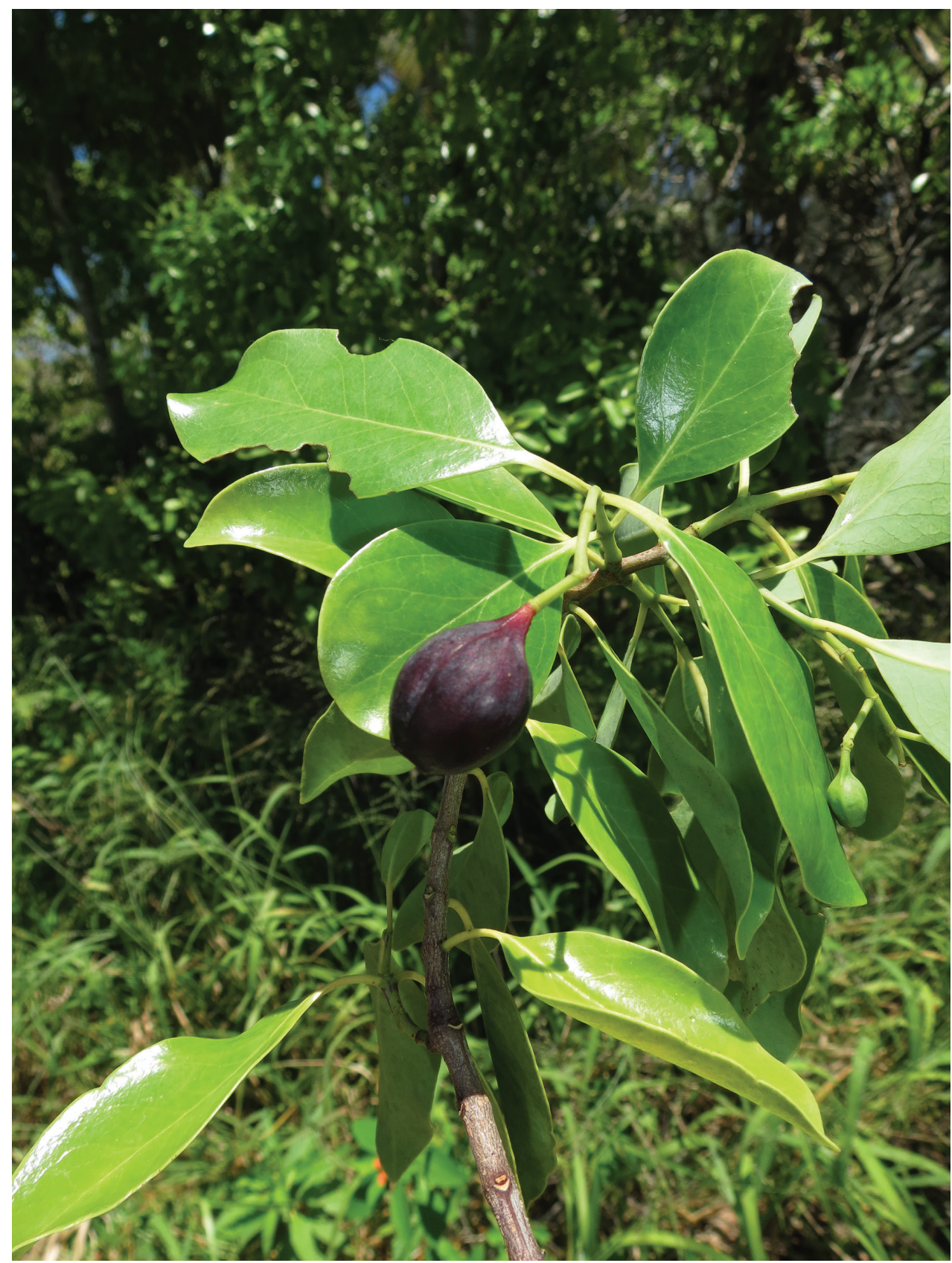

Figure 3. Fruit of Santalum austrocaledonicum var. glabrum on Ouvéa atoll in January 2015 (specimen Butaud 3414). 
Loyalty sandalwood's morphological, genetic, sylvicultural and chemical specificities (Bottin 2006, Bottin et al. 2007, Butaud et al. 2013, Ehrhart 1998). On the other hand, the sustainable exploitation of natural stands of Loyalty Islands sandalwood is becoming increasingly difficult with the lack of regeneration and the increasing international demand for sandalwood essential oil. Well-managed plantations with variety glabrum could be promoted to preserve the natural stands, to develop the Loyalty sandalwood sector, and to increase the production of heartwood and essential oil (Butaud 2011, Butaud et al. 2013).

The taxonomy of $S$. austrocaledonicum still needs to be further investigated. Indeed, the study of herbarium samples of var. austrocaledonicum and previous molecular and morphometric studies (Bottin 2006, Bouvet et al. 2005) showed significant variability. It is expected that future work supported by increased surveys and sampling of northern Grande-Terre sandalwood could reveal one or two new varieties, including one on Isle of Pines (taxon previously described as Santalum homei Seem.). Moreover, two new endemic varieties of $S$. austrocaledonicum are expected based on the recent study of Millet et al. (2012) on the genetic structure of Vanuatu sandalwood, one for the northern islands and one for the southern islands.

\section{Key to New Caledonian varieties of Santalum austrocaledonicum}

(adapted from Hallé 1988)

1 Inflorescence peduncles, rachis segments and outer surface of petals sparsely to densely hairy ............................................................................ pilosulum

- Inflorescence peduncles, rachis segments, outer surface of petals and petal internal margins glabrous........................................................................... 2

2 Leaf blade usually less than $3.5 \times 1.5 \mathrm{~cm}$; petiole less than $7 \mathrm{~mm}$; blade adaxial surface glaucous and bluish in color; interstaminal disk lobes very narrow $(\mathrm{W} / \mathrm{L}=1 / 3-1 / 4)$ var. minutum

- $\quad$ Leaf blade usually more than $3.5 \times 1.5 \mathrm{~cm}$; petiole more than $7 \mathrm{~mm}$; blade adaxial surface not glaucous and bluish in color; interstaminal disk lobes wide $(\mathrm{W} / \mathrm{L}=1 / 2)$ .3

Seed usually more than $9 \times 7.5 \mathrm{~mm}$; globose $(\mathrm{L} / \mathrm{D}<1.2)$ var. glabrum Seed usually less than $9.5 \times 7.5 \mathrm{~mm}$; ovoid (L/D > 1.2)

var. austrocaledonicum

\section{Essential oil quality}

Essential oil of Santalum austrocaledonicum was previously assessed for its composition and organoleptic properties, and was considered as a possible substitute for Indian sandalwood oil (Santalum album) but also as a promising new raw material for the fra- 
Table I. Main constituents of Loyalty Islands sandalwood (var. glabrum) essential oil compared to ISO standards for $S$. album oil.

\begin{tabular}{|c|c|c|c|}
\hline Essential oil & (Z)- $\alpha$-santalol (\%) & (Z)- $\beta$-santalol (\%) & (E)-lanceol (\%) \\
\hline $\begin{array}{c}\text { ISO Standard 3518 : 2002 } \\
\text { (S. album) }\end{array}$ & 41 to 55 & 16 to 24 & - \\
\hline $\begin{array}{c}\text { New Caledonia } \\
\text { Braun et al. (2005) }\end{array}$ & 38.2 & 18.2 & 9.1 \\
\hline Loyalty Oil 1 & 44.3 & 19.4 & 14.1 \\
\hline Loyalty Oil 2 & 47.4 & 21.3 & 8.5 \\
\hline
\end{tabular}

grance industry (Braun et al. 2005). These evaluations were performed on essential oils resulting from mixtures of sandalwood varieties glabrum (Loyalty islands), pilosulum (surroundings of Nouméa) and austrocaledonicum (Isle of Pines), leaving unknown the quality of each individual variety.

To investigate the quality of Loyalty Islands sandalwood essential oil (var. glabrum), two samples were analyzed for their main sesquiterpenoids but also for their organoleptic properties:

- Loyalty Oil 1 (EI1) obtained in 2015 from Distillerie de Boulouparis (New Caledonia) with Ouvéa sandalwood,

- Loyalty Oil 2 (EI2) obtained in 2002 from Michel Point and processed by Koop Cuada distillery with Maré and Lifou sandalwoods.

The gas-chromatography was performed on an apolar column (HP-1, $10 \mathrm{~m} \times 0.1$ $\mathrm{mm}$, film $0.1 \mathrm{~m}, 50^{\circ}\left(1^{\prime}\right)$ to $280^{\circ}\left(2^{\prime}\right)$ at $50^{\circ} / \mathrm{min}$., vector gas: hydrogen). Its results are given in Table 1 (C. Vial and S.A. Firmenich, pers. comm. 2015).

The organoleptic evaluation showed that the Loyalty essential oil is lighter and less milky than the Indian sandalwood; the former has also a character less woody but more animal and masculine (P.-A. Blanc and S.A. Firmenich, pers. comm. 2015).

These findings are in accordance with Braun et al. (2005), especially for the organoleptic evaluation. Moreover, the composition of both Loyalty essential oils meets the ISO Standard for Indian sandalwood, which was not the case for the samples of the previous study. Thus, Santalum austrocaledonicum var. glabrum or Loyalty sandalwood constitutes a true substitute for Indian sandalwood in the perfume industry.

\section{Acknowledgments}

I am grateful to the Province des Iles Loyauté (PIL) which has initiated and supported recent investigations on the Loyalty Islands flora, to the Firmenich Charitable Foundation for supporting taxonomical studies, and to the Herbier du Centre IRD de Nouméa (NOU) for access to its Santalum collections. 
I thank Gildas Gâteblé (Institut Agronomique néo-Calédonien) for helpful discussions on Loyalty Islands Santalum, and, together with David Lorence (National Tropical Botanical Garden, Hawai'i), Art Whistler, and Jacques Florence (IRD), for their important comments and corrections of previous drafts of this paper. I appreciate review comments by Daniel Nickrent and an unknown reviewer.

I am indebt to Christian Vial and Pierre-Alain Blanc (Firmenich S.A.) for, respectively, gas-chromatography analysis and organoleptic analysis of S. austrocaledonicum var. glabrum essential oils, and to Annette Olsson (Conservation International) for English wording review. I am also grateful to George Kakue, Luen Iopue, Meri Thupalua (PIL) and Jean-Christophe Lefeuvre (Conservation International) for their support and interest in establishing a Flora of Loyalty Islands, and to Selma Haouet for providing the map background.

\section{References}

Bottin L (2006) Déterminants de la variation moléculaire et phénotypique d'une espèce forestière en milieu insulaire : cas de Santalum austrocaledonicum en Nouvelle-Calédonie. PhD Thesis, ENSAM - CIRAD, Montpellier, France.

Bottin L, Tassin J, Nasi R, Bouvet JM (2007) Molecular, quantitative and abiotic variables for the delineation of evolutionary significant units: case of sandalwood (Santalum austrocaledonicum Vieillard) in New Caledonia. Conservation genetics 8(1): 99-109. doi: 10.1007/ s10592-006-9152-7

Bottin L, Verhaegen D, Tassin J, Olivieri I, Vaillant A, Bouvet JM (2005) Genetic diversity and population structure of an insular tree Santalum austrocaledonicum in New Caledonia archipelago. Molecular ecology 14: 1979-1989. doi: 10.1111/j.1365-294X.2005.02576.x

Bouvet JM, Cardi C, Verhaegen D, Butaud JF, Nasi R, Tassin J (2005) Molecular and morphometric diversity in Santalum insulare and Santalum austrocaledonicum. In: Thomson L, Bulai S, Sovea L (Eds) Proceedings of the regional workshop on sandalwood research, development and extension in the Pacific islands and Asia. 7-11 October 2002, Noumea, New Caledonia, 124-134.

Braun NA, Meier M, Hammerschmidt FJ (2005) New Caledonian Sandalwood Oil - a Substitute for East Indian Sandalwood Oil? Journal of Essential Oil Research 17: 477-480. doi: 10.1080/10412905.2005.9698969

Butaud JF (2011) Analyse bibliographique et technique des références existantes sur le santal en vue de sa valorisation économique en plantations à l'échelle de la Nouvelle-Calédonie. Rapport n¹5/2011. IAC - Programme Forêt Sèche, Nouvelle-Calédonie, 1-238.

Butaud JF, Guy L, Lefeuvre JC (2013) Etude sur l'état de la ressource naturelle en santal aux Iles Loyauté pour le développement de filières aromatiques certifiées. Conservation International \& Province des Iles Loyauté, 1-370.

Chauvin JP, Ehrhart Y (1998) Germination of two provenances of Santalum austrocaledonicum var. austrocaledonicum. In: Radomiljac AM, Ananthapadmanabho HS, Welbourn RM, Satyanarayana Rao K (Eds) Sandal and its products. Proceedings of an international 
seminar held on 18-19 December 1997 organised by the Institute of Wood Science and Technology (ICFRE) and Karnataka State Forest Department, Bangalore, India. ACIAR, 113-116.

Ehrhart Y (1998) Description of some sandal tree populations in the South West Pacific: consequences for the silviculture of these species and provenances. In: Radomiljac AM, Ananthapadmanabho HS, Welbourn RM, Satyanarayana Rao K (Eds) Sandal and its products. Proceedings of an international seminar held on 18-19 December 1997 organised by the Institute of Wood Science and Technology (ICFRE) and Karnataka State Forest Department, Bangalore, India. ACIAR, 113-116.

Guillaumin A (1925) Matériaux pour la flore de Nouvelle-Calédonie, XVIII : Révision des Santalacées. Bulletin de la Société Botanique de France 72(1): 89-91. doi: 10.1080/00378941.1925.10832717

Guillaumin A (1970) Le santal en Nouvelle-Calédonie. Journal d'agriculture tropicale et de botanique appliquée 17(7-8-9): 340-341. doi: 10.3406/jatba.1970.3073

Hallé N (1988) Santalaceae. In: Flore de la Nouvelle-Calédonie et Dépendances. Tome 15. MNHN, Paris.

Harbaugh DT (2007) A taxonomic revision of Australian northern sandalwood (Santalum lanceolatum, Santalaceae). Australian Systematic Botany 20: 409-416. doi: 10.1071/SB07009

Harbaugh DT, Baldwin BG (2007) Phylogeny and biogeography of the sandalwoods (Santalum, Santalaceae): repeated dispersal throughout the Pacific. American Journal of Botany 94: 1028-1040. doi: 10.3732/ajb.94.6.1028

Harbaugh DT, Oppenheimer HL, Wood KR, Wagner WL (2010) Taxonomic Revision of the Endangered Hawaiian Red-flowered Sandalwoods (Santalum) and Discovery of an Ancient Hybrid Species. Systematic Botany 35(4): 827-838. doi: 10.1600/036364410X539899

ISO (2002) Standard ISO 3518:2002: Oil of sandalwood (Santalum album L.). International Organization for Standardization, Geneva, Switzerland.

IUCN (2001) IUCN Red List categories (version 3.1). IUCN Species Survival Commission, Gland, Switzerland. http://www.iucnredlist.org/info/categories_criteria2001

Lenormand MH (1968) Vocabulaire des noms de plantes médicinales et alimentaires utilisées par les Mélanésiens de Lifou (Iles Loyalty). Journal d'Agriculture Tropicale et de Botanique Appliquée 15(4-5-6): 173-194. doi: 10.3406/jatba.1968.2979

Lormée N, Cabalion P, Hnawia ES (2011) Hommes et plantes de Maré, îles Loyauté, NouvelleCalédonie. IRD Editions, 1-358.

Millet L, Malapa R, Maggia L (2012) Diversité génétique des populations de Santalum austrocaledonicum (Santalaceae) au Vanuatu. Rapport Final Appel à projet 2008 - Ministère chargé de l'Outre-Mer. Institut Agronomique néo-Calédonien \& Centre Technique et de Recherche en Agronomie du Vanuatu, 1-41.

Myers N, Mittermeier RA, Mittermeier CG, da Fonseca GAB, Kent J (2000) Biodiversity hotspots for conservation priorities. Nature 403: 853-858. doi: 10.1038/35002501

Nasi RP (1994) Le genre Santalum L. en Nouvelle-Calédonie. CIRAD-forêt, Nouvelle-Calédonie. Unpublished manuscript.

Nasi RP (1995) Germination and seed dormancy in Santalum austrocaledonicum: a synopsis. In: Gjerum L, Fox JED, Ehrhart Y (Eds) Sandalwood Seed Nursery and Plantation Tech- 
nology. Proceedings of a Regional Workshop for Pacific Island Countries held at Nouméa, New Caledonia, 1-11 August 1994, FAO, Suva, Fiji. RAS/92/361. Field Document 8: 59-74.

Ozanne-Rivierre F (1984) Dictionnaire Iaai - Français (Ouvéa Nouvelle-Calédonie) suivi d'un lexique français-iaai. Laboratoire de langues et civilisations à tradition orale, CNRS, Ivrysur-Seine, France, 1-181.

Quemin C (1988) Etudes sur le santal (Santalum austrocaledonicum). Mémoire de $3^{\text {ème }}$ année ENGREF. Centre Technique Forestier Tropical, France.

Shineberg D (1967) They came for sandalwood. Melbourne University Press, 1-299.

Stauffer H, Hürlimann H (1964) Santalacées. In: Guillaumin A (Ed.) Résultats scientifiques de la Mission franco-suisse de botanique en Nouvelle-Calédonie (1950-1952) n³. Mémoires du Muséum National d'Histoire Naturelle, série B, Botanique 15(1): 14-15.

Tamla HT, Cornelius JP, Page T (2012) Reproductive biology of three commercially valuable Santalum species: development of flowers and inflorescences, breeding systems, and interspecific crossability. Euphytica 184: 323-333. doi: 10.1007/s10681-011-0530-y

Vieillard E (1861) Plantes utiles de la Nouvelle-Calédonie. Annales des Sciences Naturelles Botanique, série 4 - 16: 28-76.

Virot R (1950) Le santal néo-calédonien. Revue internationale de botanique appliquée et d'agriculture tropicale 30: 79-86.

\section{Appendix}

\section{Specimens examined}

Santalum austrocaledonicum var. glabrum Hürl.: New Caledonia, Loyalty Islands.

Ouvéa. Lékine, 15 May 1976, D. Bourret 815 (NOU); Lekiny, bord de route goudronnée, 24 January 2015, J.-F. Butaud 3414 (NOU); Lekiny, bord de route goudronnée, 24 January 2015, J.-F. Butaud 3415 (NOU); Lekiny, bord de route goudronnée, 24 January 2015, J.-F. Butaud 3416 (NOU); Mouli, bord de route goudronnée, 24 January 2015, J.-F. Butaud 3417 (NOU); Hnyimehe, route menant à la salle omnisport, 24 January 2015, J.-F. Butaud 3421 (NOU); Hwaadrila, piste carrossable menant au Cap St Hilaire, 25 January 2015, J.-F. Butaud 3422 (NOU); St Joseph, 14 August 1925, A.U. Däniker 2546 (P scan, Z n.v.); SaintPaul, 10 m, forêt, February 1980, H.S. MacKee 37848 leg. Douheret (NOU, P scan); Nimaha, 29 April 1987, H.S. MacKee 43516 leg. Cherrier (NOU, P scan, Z n.v.); Nimaha, 29 April 1987, H.S. MacKee 43517leg. Cherrier (P scan); Hanawa, forêt dense littorale, 29 April 1987, H.S. MacKee 43520 leg. Cherrier (P scan); Hanawa, forêt dense littorale, 30 April 1987, H.S. MacKee 43526 leg. Cherrier (NOU, P scan); Pointe de Mouli, 30 April 1987, H.S. MacKee 43527 leg. Cherrier (NOU, P scan); Wakat, 30 April 1987, H.S. MacKee 43530 leg. Cherrier (NOU, P scan); Wakat, 30 April 1987, H.S. MacKee 43532 leg. Cherrier (NOU, P scan); Gossanat, forêt, 11 May 1987, H.S. MacKee 43545 leg. Ongat (NOU, P scan); Gossanat, forêt, 11 May 1987, H.S. MacKee 43546 leg. Ongat (NOU, P scan); ); 
Teouta, 11 May 1987, H.S. MacKee 43547 leg. Ongat (NOU, P scan); Teouta, 11 May 1987, H.S. MacKee 43548 leg. Ongat (P scan); Ogniat, en lisière d'une cocoteraie, 11 May 1987, H.S. MacKee 43549 leg. Ongat (P scan); Ogniat, en lisière d'une cocoteraie, 11 May 1987, H.S. MacKee 43550 leg. Ongat (P scan); Takedji, 11 May 1987, H.S. MacKee 43551 leg. Ongat (NOU, P scan); Takedji, 11 May 1987, H.S. MacKee 43552 leg. Ongat (NOU, P scan); 19 July 1984, P. Morat 7782 (NOU).

Lifou. July 1869, B. Balansa 1692b (P scan); 1928, C. Bergeret 106 (P scan); Mutschaweng, $30 \mathrm{~m}$, lisière de forêt, 18 February 1974, H.S. MacKee 28169 (P scan, Z n.v.); Natchaom, 5 June 1987, H.S. MacKee 43577 leg. Wapae (P scan); Natchaom, 5 June 1987, H.S. MacKee 43578 leg. Wapae (P scan); Natchaom, 5 June 1987, H.S. MacKee 43579 leg. Wapae (P scan); Ouanaham, 3 August 1987, H.S. MacKee 43638 leg. Case (NOU, P scan); Hunete, 4 August 1987, H.S. MacKee 43639 leg. Case (P scan); Hunete, dans un jardin, 4 August 1987, H.S. MacKee 43640 leg. Case (NOU, P scan); Hunete, 4 August 1987, H.S. MacKee 43641 leg. Case (NOU, P scan); March 1979, J.-M. Veillon 3920 leg. Lespès (NOU); March 1979, J.-M. Veillon 3921 leg. Lespès (NOU, P scan).

Maré. Medu, dans les fourrés, 22 December 1925, A.U. Däniker 2546a (P scan, Z n.v.); E.I. Franc 1286 (P scan); La Roche, fourré secondaire, 24 April 1987, H.S. MacKee 43602 leg. Cornaille (NOU, P scan); La Roche, fourré secondaire, 24 April 1987, H.S. MacKee 43603 leg. Cornaille (NOU, P scan); Hnadid, 3 August 1987, H.S. MacKee 43620 leg. Cornaille (NOU, P scan); Hnadid, fourré secondaire, 3 August 1987, H.S. MacKee 43621 leg. Cornaille (NOU, P scan); Wakone, fourré secondaire, 3 August 1987, H.S. MacKee 43622 leg. Cornaille (NOU, P scan); Tawainedre, Pewaete, fourré secondaire, 3 August 1987, H.S. MacKee 43623 leg. Cornaille (NOU, P scan); Tawainedre, Pewaete, fourré secondaire, 3 August 1987, H.S. MacKee 43624 leg. Cornaille (NOU, P scan); Cuadene, lisière de forêt, 3 August 1987, H.S. MacKee 43625 leg. Cornaille (NOU, P scan); Penelo, fourré, 3 August 1987, H.S. MacKee 43626 leg. Cornaille (NOU, P scan); Penelo, fourré secondaire, 3 August 1987, H.S. MacKee 43627 leg. Cornaille (NOU, P scan); La Roche, jardin abandonné, 3 August 1987, H.S. MacKee 43628 leg. Cornaille (NOU, P scan); Penelo, Dadac, fourré secondaire, 3 August 1987, H.S. MacKee 43629 leg. Cornaille (NOU, P scan); Peyece, fourré secondaire, 3 August 1987, H.S. MacKee 43630 leg. Cornaille (NOU); Kaewatine, fourré secondaire, 3 August 1987, H.S. MacKee 43631 leg. Cornaille (NOU, P scan); Thogone, fourré secondaire, 3 August 1987, H.S. MacKee 43632 leg. Cornaille (NOU, P scan); Ro, fourré secondaire, 3 August 1987, H.S. MacKee 43633 leg. Cornaille (NOU, P scan); Pede, 3 August 1987, H.S. MacKee 43634 leg. Cornaille (NOU, P scan); Pede, lisière de forêt, 3 August 1987, H.S. MacKee 43635 leg. Cornaille (NOU, P scan); Eni, dans un jardin, 3 August 1987, H.S. MacKee 43636 leg. Cornaille (NOU, P scan, Z n.v.); Eni, cocoteraie littorale, 3 August 1987, H.S. MacKee 43637 leg. Cornaille (NOU, P scan); 31 August 1987, H.S. MacKee 43679 (NOU, P scan). 
Santalum austrocaledonicum Vieill. var. austrocaledonicum:

New Caledonia, Grande-Terre. Arama, collines près de la mer, 1855-60, E. Vieillard 1090 (holotype: P scan; isotypes: P [2] scan, K p.p. scan); Arama, collines près de la mer, 1855-60, E. Vieillard 1090bis (P scan; K p.p. scan); Vavouto, 26 September 2007, J. Munzinger 4518 (NOU); Presqu'île de Pindai, propriété Kuhn, 2 July 1987, J.M. Veillon 6422 (NOU, P scan); Presqu'île de Népoui, Pindai, 100 m, 18 November 1987, J.M. Veillon 6574 (NOU, P scan); Presqu'île de Pindai, 100 m, 1 April 1988, J.M. Veillon 6794 (NOU, P scan); Poya, forêt de Nekoro, 5 m, 28 September 1988, J.M. Veillon 6917 (NOU); Poya, station de Mueo, propriété Johnston entre 10-20 m, 6 May 1998, J.M. Veillon 8106 (NOU); Poya, station de Mueo, propriété Johnston entre 10-20 m, 6 May 1998, J.M. Veillon 8107 (NOU, P scan).

New Caledonia, Isle of Pines. 1852, Home s.n. (BM scan); 1853, MacGillivray 8186 (K scan); ); Kuto, 1 February 1980, H.S. MacKee 37852 leg. Douheret (NOU, P scan); Kuto, 9 February 1980, H.S. MacKee 37853 leg. Douheret (NOU, P scan); Kuto, 1 February 1980, H.S. MacKee 37872 leg. Sevenet (NOU, P scan); Kuto, 1 February 1980, H.S. MacKee 37873 leg. Sevenet (NOU, P scan); Plateau, 25 February 1980, H.S. MacKee 37874 leg. Sevenet (NOU, P scan); Ouro, 7 October 1987, H.S. MacKee 43738 leg. Quemin (NOU, P scan); Ouro, 9 October 1987, H.S. MacKee 43739 leg. Quemin (NOU, P scan); Kuto, 9 October 1987, H.S. MacKee 43740 leg. Quemin (NOU, P scan); Ouameo, 8 October 1987, H.S. MacKee 43741 leg. Quemin (NOU, P scan); Oupotoue, Gadji, 8 October 1987, H.S. MacKee 43742 leg. Quemin (NOU, P scan).

Santalum austrocaledonicum var. pilosulum N.Hallé: New Caledonia, Grande-Terre. Nouméa, Ouen Toro, $50 \mathrm{~m}$, forêt côtière sur pente caillouteuse schisteuse 29 December 1971, H.S. MacKee 24766 (holotype: P scan); Mont Dore, Ilot Pêcheur, 27 January 2015, G. Gâteblé 708 (IAC); Paita, Stand de Tir, 27 January 2015, G. Gâteblé 709 (IAC); Ouen Toro, March-April 1983, Herbier Convention 10 (NOU); Ouen Toro, 12 February 1979, M. Hoff 184 (NOU); Nouméa, île Nou, 5 February 1978, H.S. MacKee 34688 (NOU, P scan); Plantule provenance Ouen Toro, Port-Laguerre, Paita, 1 October 1982, H.S. MacKee 40837 (NOU, P scan); Nouméa, Ouen Toro, 50 m, 26 June 1987, H.S. MacKee 43600 (NOU, P scan); Plantule provenance Ouen Toro, Port-Laguerre, Paita, 17 August 1987, H.S. MacKee 43657 (NOU, P scan); Ouen Toro hill at $S$ End of Noumea, $50 \mathrm{~m}$, 31 January 1982, G. MacPherson 4558 (NOU, P scan); Nouméa, Anse Vata, SWHang des Mt Ouen Toro, 100 m, 22 February 1964, H.U. Stauffer 5701 (NOU, P scan, Z n.v.); Nouméa, Anse Vata, SW-Hang des Mt Ouen Toro, 100 m, 22 February 1964, H.U. Stauffer 5702 (NOU, P scan, Z n.v.); Areal der IFO, Anse Vata, Nouméa, 11 March 1964, H.U. Stauffer 5792 (NOU, P scan, Z n.v.); IFO, Anse Vata, 6 January 1965, J.M. Veillon 18 (NOU, P scan); Nouméa, Colline du Ouen Toro, 1 April 1969, J.M. Veillon 1934 (NOU, P scan).

Santalum austrocaledonicum var. minutum N.Hallé: New Caledonia, Grande-Terre. Montagne de Poum, pic 272, versant Est, 50 m, arbuste 3m, 25 March 1982, 
J.M. Veillon 4852 (holotype: P n.v.; isotype NOU scan); Arama, collines près de la mer, 1855-60, E. Vieillard 1090ter (P scan); Koumac, Camp militaire, SMA, 8 August 1994, A. Dessert 2 (NOU); Koumac, Babouillat, 14 June 2014, G. Gâteblé 518 (IAC); Entrée de Koumac, terrain du SMA, 16 December 1994, T. Jaffré 3257 (NOU, P scan); Au pied de la Tiebaghi 18 October 1970, M. Schmid 3465 (NOU); Montagne de Poum, 25 March 1982, B. Suprin 1744 (NOU); Montagne de Poum, 9 June 1982, B. Suprin 1948 (NOU); Koumac, Camp militaire, SMA, 9 August 1994, B. Suprin 2435 (NOU). 